\title{
Hemodiyaliz Tedavisi Alan Bireylerin Sıvı Kısıtlamasına Uyum Düzeyleri
}

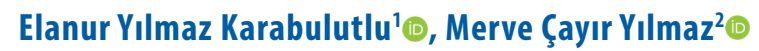

'Atatürk Üniversitesi Hemşirelik

Fakültesi, Erzurum, Türkiye

2Amasya Üniversitesi, Sağlık Bilimleri

Fakültesi, Amasya, Türkiye

Elanur Yılmaz Karabulutlu, Prof. Dr. Merve Çayır Yılmaz, Dr. Öğr. Üyesi

İletişim:

Dr. Öğr. Üyesi Merve Çayır Yılmaz Amasya Üniversitesi, Sağılk Bilimleri Fakültesi, Amasya, Türkiye

Tel: +905428042263

E-Posta: mervehemsiiire@hotmail.com

Gönderilme Tarihi : 02 Kasım 2017

Revizyon Tarihi : 01 Aralık 2017

Kabul Tarihi : : 04 Aralık 2017
ÖZET

Amaç: Bu araştırma, hemodiyaliz tedavisi alan bireylerin sıvı kısıtlamasına uyum düzeylerini değerlendirmek ve sıvı kısıtlamasına uyumu etkileyen faktörleri belirlemek amacıyla yapılmıştır.

Gereç ve Yöntem: Tanımlayıı tipte olan bu araştırma Aralık 2016 - Şubat 2017 tarihleri arasında 88 hemodiyaliz tedavisi alan birey ile yürütülmüş̧ür. Verilerin toplanmasında Hasta Tanıtıı Formu ve Hemodiyaliz Hastalarında Sıvı Kontrol Ölçeği (HHSKÖ) kullanıımıştır. Veriler Student t testi, tek yönlü varyans analizi (ANOVA), Kruskal Wallis H testi, Mann Whitney U testi, LSD Post Hoc testi, Pearson Momentler Çarpımı Korelasyon analizleri kullanılarak değerlendirilmiştir.

Bulgular: Hemodiyaliz tedavisi alan bireylerin sIvı kontrol uyumları orta düzeyde bulunmuş olup $(51.23 \pm 5.88)$, bireylerin sIVI kontrol bilgi düzeylerinin yüksek olduğu $(20.22 \pm 1.07)$, davranış boyutu açısından orta seviyede bir uyuma sahip oldukları $(22.42 \pm 4.23)$ ve tutum boyutunda uyum düzeylerinin düşük olduğu $(8.59 \pm 2.61)$ görülmüşsür. Bireylerin sıvı kontrol uyumlarına cinsiyet ve medeni durumun, bilgi düzeylerine cinsiyet ve tedavi süresinin, davranışlarına ise cinsiyetin anlamlı düzeyde etki ettiği belirlenmiştir. Kadınların bilgi boyutu, davranış boyutu ve toplam sıvı kontrol uyum düzeylerinin erkeklerden daha yüksek olduğu, bekarların toplam sıvı kontrol uyum düzeylerinin evlilerden daha yüksek olduğu ve hemodiyaliz tedavi süresi 6 ay-2 yıl olanların diğer gruplara göre sıvı kontrolüne ilişkin bilgi düzeylerinin daha düşük olduğu bulunmuştur. Sıvı kontrolü uyumunda tutum ve toplam puanların artması ile interdiyalitik kilo alımının azaldığı, davranış ve toplam puanların atması ile ise ultrafiltrasyon miktarının azaldığı tespit edilmiştir.

Sonuç: Hemodiyaliz tedavisi alan bireylerin sıvı kısıtlamasına yeterince uyum geliştiremedikleri belirlenmiş olup, sıvı kısıtlamasına uyumu arttırmaya yönelik her bireye özgü eğitim ve uygulamalara ihtiyaç vardır.

Anahtar sözcükler: Hemodiyaliz, sıvı kontrolü, uyum, interdiyalitik kilo

\section{LEVEL OF CONCORDANCE WITH FLUID RESTRICTION IN INDIVIDUALS RECEIVING HEMODIALYSIS}

\section{ABSTRACT}

Aim: This study aims to identify the level of compatibility with fluid restriction and the affecting factors in individuals receiving hemodialysis treatment.

Materials and Methods: This descriptive study was conducted with 88 individuals who received hemodialysis treatment between December 2016 and February 2017. Data were collected using the Patient Identification Form and Fluid Control Scale in Hemodialysis Patients (FCSHP) and analysed using student t-test, one-way analysis of variance (ANOVA), Kruskal Wallis H test, Mann Whitney $U$ test, LSD Post Hoc test, and Pearson Moment Correlation analysis.

Results: It was found that the individuals who received hemodialysis treatment had a medium compatibility level with fluid restriction (51.23 \pm 5.88$)$; they had high fluid restriction knowledge levels $(20.22 \pm 1.07)$; and they had a medium compatibility level in terms of the behavioral aspects $(22.42 \pm 4.23)$ and a low compatibility level in terms of the attitudes aspect $(8.59 \pm 2.61)$. Individuals' compatibility with fluid restriction was found to be affected by gender and marital status; knowledge level was found to be affected by gender and treatment duration, and behaviors were affected by gender significantly. Women were found to have higher compatibility levels in terms of knowledge, behavior and total fluid control aspects compared to men; single patients' level of total fluid control compatibility was higher compared to married patients, and level of knowledge about fluid control compatibility was lower in patients who had treatment duration of 6 months to 2 years compared to other groups. Interdialytic weight gain decreased with the increase in the attitudes and total scores in fluid control compatibility, and the amount of ultrafiltration decreased with the increase in behavior and total scores.

Conclusion: It was found that individuals who received hemodialysis treatment were not compatible enough with the fluid restriction, personalized trainings and practices are required for increasing compatibility with fluid restriction.

Keywords: Hemodialysis, fluid control, concordance, interdialytic weight 
on dönem böbrek yetmezliği (SDBY) insidans ve prevalansı her geçen gün artmaktadır $(1,2)$. SDBY tanısı alan hastalarda hemodiyaliz (HD), periton diyalizi (PD) ve böbrek transplantasyonu gibi renal replasman tedavi (RRT)'leri uygulanmaktadır. RRT'leri yaşamı koruyucu tedavilerdir ve uygulanan en yaygın yöntem HD'dir (3,4). Ülkemizde 2014 yılında SDBY olan 71.318 hastanın RRT aldığı, toplam HD hasta sayısının ise 55.890 olduğu bildirilmiştir (2).

HD tedavisinin, mortaliteyi azaltıp beklenen yaşam süresini uzattığı bilinmekle beraber fiziksel, psikolojik, sosyal ve ekonomik alanlarda çeşitli istenmeyen sorunlara sebep olduğu da bilinmektedir. SDBY sonucu HD'e giren bireylerde sıvı alımı, yiyeceklerin kısıtlanması, ilaçların yan etkileri, yorgunluk, geleceğin belirsizliği, aile bireylerinin rol ve sorumluluklarındaki değişiklikler, bir makinaya bağımlı olma, tedavi süresi nedeniyle vakit kaybı, cinsel fonksiyon bozukluğu, anksiyete ve depresyon gibi ruhsal sorunlar, mali sorunlar ve iş kaybı gibi pek çok sorun yaşanmaktadır $(5,6,7,8,9,10,11,12)$. Yaşam düzenine ve kalitesine olan bu etkileri sebebiyle HD tedavisinin; yalnızca hasta ömrünü arttırmak amacıyla değil, aynı zamanda hastanın kaliteli bir yaşam sürmesini sağlamak amacıyla uygulanması gerektiği fikri önem kazanmıştır $(13,14)$.

HD hastalarında yaşam kalitesinin arttırılması ve mortalitenin azaltılmasında tedaviye uyum hayati öneme sahiptir $(3,4,14,15,16,17,18)$. HD'de diyet, sıvı alımı ve diyaliz seansları gibi pek çok faktörü içeren tedaviye uyum kavramı, tedavi rejiminin kendisi kadar etkin ve önemlidir. Ömür boyu HD ve ilaç tedavisi almak zorunda olan bu hastalar sıvı ve diyet kısıtlamaları da dahil olmak üzere bir çok alanda davranış değişikliği geliştirmek durumundadır. Başarılı HD tedavisi için; sıvı kısıtlamasının, diyet rehberinin, ilaç reçetelerinin dikkate alınması ve HD seanslarına düzenli katılım gerekir $(4,19,20)$.

HD'de en fazla stres yaratan ve tedaviye uyumda zorlanılan alan sıvı kısıtlamasıdır $(4,19,21,22,23,24,25)$. Hastalık ilerledikçe HD hastaları idrar oluşturma yeteneklerini kaybeder. Bu nedenle, tüketilen sıvının miktarı önem kazanır (26). Bu hastalar arasında aşırı interdiyalitik kilo alımı (IDWG) sık görülen bir sorundur. Bu sorun tedavi sırasında nefes darlığı, kas krampı, baş dönmesi, hipotansiyon gibi akut semptomlara yol açmanın yanı sıra, kardiyovasküler hastalıklara ve erken ölümlere de neden olmaktadır $(4,25,27,28,29)$.

Sıvı alımı uyumunun sağlanması, HD tedavisinin başlıca hedeflerinden biridir. Alınan sıvı miktarını saptamak için dikkate alınan en önemli klinik parametre IDWG olmakla beraber tek başına sıvı alımı uyumunu değerlendirmek için yeterli değildir. Hastanın rezidüel böbrek fonksiyonu ve kuru ağırlığı da uyumu değerlendirmede dikkate alınan önemli parametrelerdir (30,31,32). Alınan sıvıyı dengelemenin en uygun yolu, hedeflenen diyaliz sonrası ağırlığın ayarlanması ve IDWG'nin sınırlandırılmasıdır (33).

HD hastalarında tedaviye uyumun önemli bir parçası olan sıvı kısıtlamasına uyumun ele alınmasıyla tedavinin etkinliği arttırılarak, daha iyi sağlık sonuçlarına ulaşmak mümkündür $(20,34)$.

Bu araştırma, HD tedavisi alan bireylerin sIVı kısıtlamasına uyum düzeylerini değerlendirmek ve sıvı kısıtlamasına uyumu etkileyen faktörleri belirlemek amacıyla yapılmıştır.

\section{Gereç ve yöntem}

Araştırmanın amacı ve türü: Araştırma, HD tedavisi alan bireylerin sıvı kısıtlamasına uyum düzeylerini değerlendirmek ve sıvı kısıtlamasına uyumu etkileyen faktörleri belirlemek amacıyla tanımlayıcı olarak yapılmıştır.

Araştırmanın yapıldığı yer ve zaman: Araştırma, Erzurum Bölge Eğitim ve Araştırma Hastanesi, Atatürk Üniversitesi Yakutiye Araştırma Hastanesi ve Ağrı Devlet Hastanesi diyaliz merkezlerinde Aralık 2016 - Şubat 2017 tarihleri arasında yapılmıştır.

Araştırmanın evreni ve örneklemi: Araştırmanın evrenini Erzurum Bölge Eğitim ve Araştırma Hastanesi diyaliz merkezinde tedavi gören kayıtlı 80 hasta, Atatürk Üniversitesi Yakutiye Araştırma Hastanesi diyaliz merkezinde tedavi gören kayıtlı 58 hasta ve Ağrı Devlet Hastanesi diyaliz merkezinde tedavi gören kayıtlı 50 hasta olmak üzere toplam 188 hasta oluşturmuştur. Herhangi bir örnekleme yöntemine başvurulmadan araştırmaya dahil edilme kriterlerine uygun tüm hastalar araştırmaya dahil edilmiştir. Araştırmaya dahil edilme kriterleri 18 yaş üstü olmak, en az 6 aydır HD tedavisi almak, okur-yazar ve işbirliğine açık olmak, görme ve işitme ile ilgili duyu kaybı olmamak, psikiyatrik rahatsızığı bulunmamak ve araştırmaya katılmayı kabul etmektir. Örneklemi, kriterlere uygun 88 hasta oluşturmuştur. Yapılan güç analizinde, \%95 güven aralığında ve 0.05 anlamlılık düzeyinde çalışmanın gücü 0.91 olarak hesaplanmıştır. Bu değer örneklemin yeterli olduğuna işaret etmektedir.

Verilerin toplanması: Veriler HD tedavisi alan bireylerin yaşı, cinsiyeti, medeni durumu gibi tanıtıcı özelliklerini, kuru ağırlık, diyaliz öncesi ve sonrası kilo, IWDG gibi 
tedaviye ilişkin değerlerini ve hemotokrit, hemoglobin, albümin gibi biyokimyasal değerlerini içeren Hasta Tanıtım Formu ve Hemodiyaliz Hastalarında Sıvı Kontrol Ölçeği (HHSKÖ) ile toplanmıştır.

HHSKÖ, HD hastalarının sıvı kısıtlaması hakkında bilgi, davranış ve tutumlarını ölçmek amacıyla Çınar ve Albayrak Coşar (2012) tarafından geliştirilmiştir. Ölçekte toplam 24 madde ve üç alt boyut bulunmaktadır. Bilgi alt boyutu: 1.7. sorulardan, Davranış alt boyutu 8.-18. sorulardan Tutum alt boyutu 19.-24. sorulardan oluşmaktadır. Ölçeğin değerlendirilmesinde $1,2,3,4,5,8,9,10,11,12,13,14$, $15,16,17$, nolu maddeler pozitif yönde ("Katılıyorum" 3 , "Kararsızım" 2, "Katılmıyorum" 1) puanlanmaktadır. 6, 7, 18, $19,20,21,22,23,24$ nolu maddeler ise ters yönde puan almaktadır. Ölçekten alınan en düşük puan 24 en yüksek puan 72'dir. Ölçekten alınan puan arttıkça hastaların Sıvı kontrolüne uyumu da artmaktadır. Ölçeğin Cronbach alfa iç tutarlılık kat sayıları; bilgi alt boyutu için 0.92, davranış alt boyutu için 0.80 , tutum alt boyutu için 0.67 'dir (35). Bu araştırmada ise ölçeğin Cronbach alfa iç tutarlılık kat sayıları; bilgi alt boyutu için 0.27 , davranış alt boyutu için 0.67 , tutum alt boyutu için 0.67 'dir.

Veriler, HD seansı sırasında yüz yüze görüşme tekniği kullanılarak ortalama 15-20 dakikalık bir sürede toplanmıştır.

Verilerin değerlendirilmesi: Elde edilen veriler SPSS (Statistical Package for Social Science) 22 yazilım programında veri tabanı oluşturularak değerlendirilmiştir. Frekans, yüzde, Student $t$ testi, tek yönlü varyans analizi (ANOVA), Kruskal Wallis $\mathrm{H}$ testi, Mann Whitney $\mathrm{U}$ testi, LSD Post Hoc testi, Pearson Momentler Çarpımı Korelasyon analizleri kullanılmıştır.

Araştırmanın sınırlılığı: HHSKÖ bilgi alt boyutu Cronbach alfa iç geçerlilik katsayısının düşük bulunması araştırmanın sınırlıı̆ı̆ olarak kabul edilmiştir.

Araştırmanın etik yönü: Araştırma öncesinde kurumlardan yazılı onam, araştırmanın amacı anlatılarak hastalardan da sözlü onam alınmıştır.

\section{Bulgular}

Hastaların, \%42'sinin 46-64 yaş, \%59.1'inin erkek, \%72.7'sinin evli, \%77.3'ünün çocuk sahibi, \%50'sinin ilkokul mezunu, \%55.7'sinin herhangi bir iş yapmadığı, \%39.8'inin orta gelirli olduğu, $\% 80,7$ 'sinin eşi veya çocuklarıyla yaşadığı, \%93.2'sinin bakım konusunda desteklendiği, \%52.3'ünün tanı aldıktan sonraki ilk 1 aylık süreçte HD
Tablo 1. Hastaların tanıtıcı ve hastalıkla ilişkili özellikleri ile ilgili bulgular $(\mathrm{n}=88)$

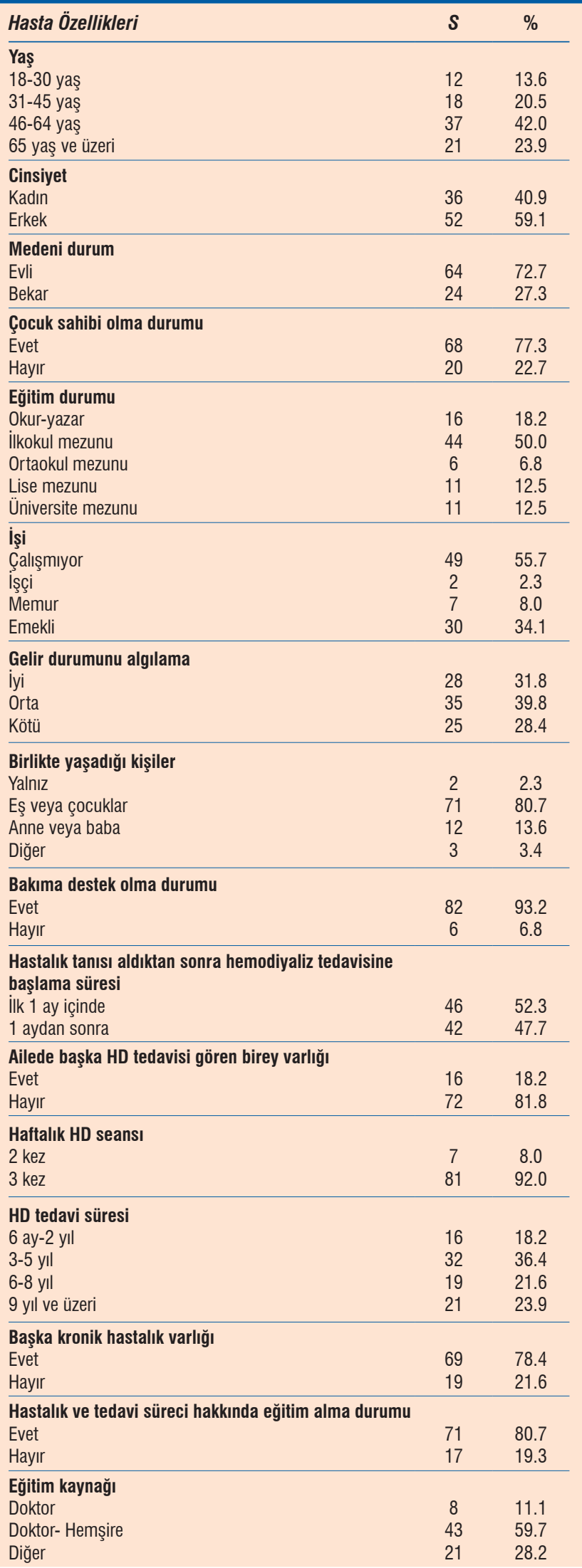




\begin{tabular}{lcccc} 
& Minimum & Maximum & Ortalama & Standart Sapma \\
\hline Kuru ağırlık & 38 & 116 & 66.45 & 16.06 \\
Diyaliz öncesi kilo & 40 & 119 & 69.61 & 16.34 \\
Diyaliz sonrası kilo & 39 & 117 & 66.70 & 16.05 \\
IDWG & 1 & 9 & 3.15 & 1.31 \\
UF miktarı & 1 & 5.80 & 3.25 & 1.14 \\
Diyaliz öncesi kan basıncı $(\mathrm{mm} / \mathrm{Hg})$ & $70 / 10$ & $180 / 90$ & $130.57 / 63.90$ & $25.29 / 23.57$ \\
Diyaliz sonrası kan basıncı $(\mathrm{mm} / \mathrm{Hg})$ & $70 / 10$ & $180 / 90$ & $121.14 / 67.56$ & $26.58 / 18.43$
\end{tabular}

tedavisine başladığı, \%81.8'inin ailesinde başka HD tedavisi alan birey olmadığı, \%92'sinin haftada 3 kez HD'e geldiği, \%36.4'ünün HD tedavi süresinin 3-5 yıl olduğu, \%78.4'ünün başka bir kronik hastalığa sahip olduğu, $\% 80.7$ 'sinin hastalık ve tedavi süreci hakkında eğitim aldığı, \%59.7'sinin ise eğitimi doktor ve hemşireden almış olduğu görülmüştür (Tablo 1).

Hastaların tedaviye ait değerlerinden, kuru ağırlık ortalaması $66.45 \pm 16.06$, diyaliz öncesi kilo ortalaması $69.61 \pm 16.34$, diyaliz sonrası kilo ortalaması $66.70 \pm 16.05$, interdiyalitik kilo ortalaması $3.15 \pm 1.31$, UF miktarı ortalaması 3.25 \pm 1.14 , diyaliz öncesi kan basıncı $(\mathrm{mm} / \mathrm{Hg})$ ortalaması 130.57/63.90, diyaliz sonrası kan basıncı $(\mathrm{mm} / \mathrm{Hg})$ ortalaması 121.14/67.56 olarak bulunmuştur (Tablo 2).

Hastaların biyokimyasal değerlerinden, hemotokrit (\%) ortalaması $35.33 \pm 5.10$, hemoglobin ( $\mathrm{gr} / \mathrm{dL}$ ) ortalaması $11.52 \pm 1.51$, albumin ( $\mathrm{gr} / \mathrm{dL}$ ) ortalaması $3.81 \pm 0.38$, total protein $(\mathrm{gr} / \mathrm{dL})$ ortalaması $6.55 \pm 0.62$, glukoz $(\mathrm{mg} / \mathrm{dL})$ ortalaması $129.05 \pm 77.96$, kalsiyum $(\mathrm{mg} / \mathrm{dL})$ ortalaması $8.42 \pm 0.81$, fosfor $(\mathrm{mg} / \mathrm{dL})$ ortalaması $5.11 \pm 1.40, \mathrm{HbA} 1 \mathrm{c}$ (\%) ortalaması $5.69 \pm 2.11, \mathrm{Kt} / \mathrm{V}$ ortalaması $1.41 \pm 0.22$, BUN $(\mathrm{mg} / \mathrm{dL})$ ortalaması $90.67 \pm 43.36$, kreatinin $(\mathrm{mg} / \mathrm{dL})$ ortalaması $8.90 \pm 2.22$, potasyum (mmol/L) ortalaması $5.02 \pm 0.96$, sodyum (mmol/L) ortalaması $136.94 \pm 3.32$ olarak bulunmuştur (Tablo 3).

Hastaların HHSKÖ “Bilgi” alt boyutu ortalaması 20.22 \pm 1.07 , "Davranış" alt boyutu ortalaması 22.42 \pm 4.23 , "Tutum" alt boyutu ortalaması $8.59 \pm 2.61$ ve "HHSKÖ toplam puan" ortalaması $51.23 \pm 5.88$ olduğu görülmüştür (Tablo 4).

Hastaların yaşlarına göre HHSKÖ "Bilgi" alt boyutu, "Davranış" alt boyutu, "Tutum" alt boyutu ve "HHSKÖ toplam puanları" açısından aldıkları puanlar arasındaki fark istatistiksel olarak anlamsız bulunmuştur ( $p>0.05$ ) (Tablo 5).
Tablo 3. Hastaların biyokimyasal değerleri

\begin{tabular}{lcccc} 
& Minimum & Maximum & Ortalama & $\begin{array}{c}\text { Standart } \\
\text { Sapma }\end{array}$ \\
\hline Hemotokrit (\%) & 24 & 51 & 35.33 & 5.10 \\
Hemoglobin (gr/dL) & 8 & 15 & 11.52 & 1.51 \\
Albumin (gr/dL) & 3 & 5 & 3.81 & 0.38 \\
Total_Protein (gr/dL) & 5 & 8 & 6.55 & 0.62 \\
Glukoz (mg/dL) & 61 & 484 & 129.05 & 77.96 \\
Kalsiyum (mg/dL) & 7 & 10 & 8.42 & 0.81 \\
Fosfor (mg/dL) & 2 & 11 & 5.11 & 1.40 \\
HbA1c (\%) & 1 & 13 & 5.69 & 2.11 \\
Kt/V & 1 & 2 & 1.41 & 0.22 \\
BUN (mg/dL) & 28 & 236 & 90.67 & 43.36 \\
Kreatinin (mg/dL) & 4 & 16 & 8.90 & 2.22 \\
Potasyum (mmol/L) & 4 & 11 & 5.02 & 0.96 \\
Sodyum (mmol/L) & 126 & 146 & 136.94 & 3.32
\end{tabular}

Tablo 4. Hastaların HHSKÖ puan ortalamaları

\begin{tabular}{lcccc} 
& Minimum & Maximum & Ortalama & $\begin{array}{c}\text { Standart } \\
\text { Sapma }\end{array}$ \\
\hline Bilgi alt boyutu & 16 & 21 & 20.22 & 1.07 \\
Davranı̧̧ alt boyutu & 11 & 31 & 22.42 & 4.23 \\
Tutum alt boyutu & 6 & 18 & 8.59 & 2.61 \\
HHSKÖ toplam puan & 37 & 64 & 51.23 & 5.88
\end{tabular}

Hastaların cinsiyetlerine göre HHSKÖ "Bilgi" alt boyutu, "Davranış" alt boyutu ve "HHSKÖ toplam puanları" açısından aldıkları puanlar arasındaki fark istatistiksel olarak anlamlı iken $(p<0.05)$, "Tutum" alt boyutu açısından aldıkları puanlar arasındaki fark anlamsız bulunmuştur ( $p>0.05$ ) (Tablo 5). Kadın hastaların HHSKÖ "Bilgi" alt boyutu, "Davranış" alt boyutu ve "HHSKÖ toplam puanları" aritmetik ortalamasının erkeklerden daha yüksek olduğu görülmüştür. 
Tablo 5. Hastaların bazı tanıtııı ve hastalıkla ilişkili özelliklerine göre HHSKÖ puan ortalamaları

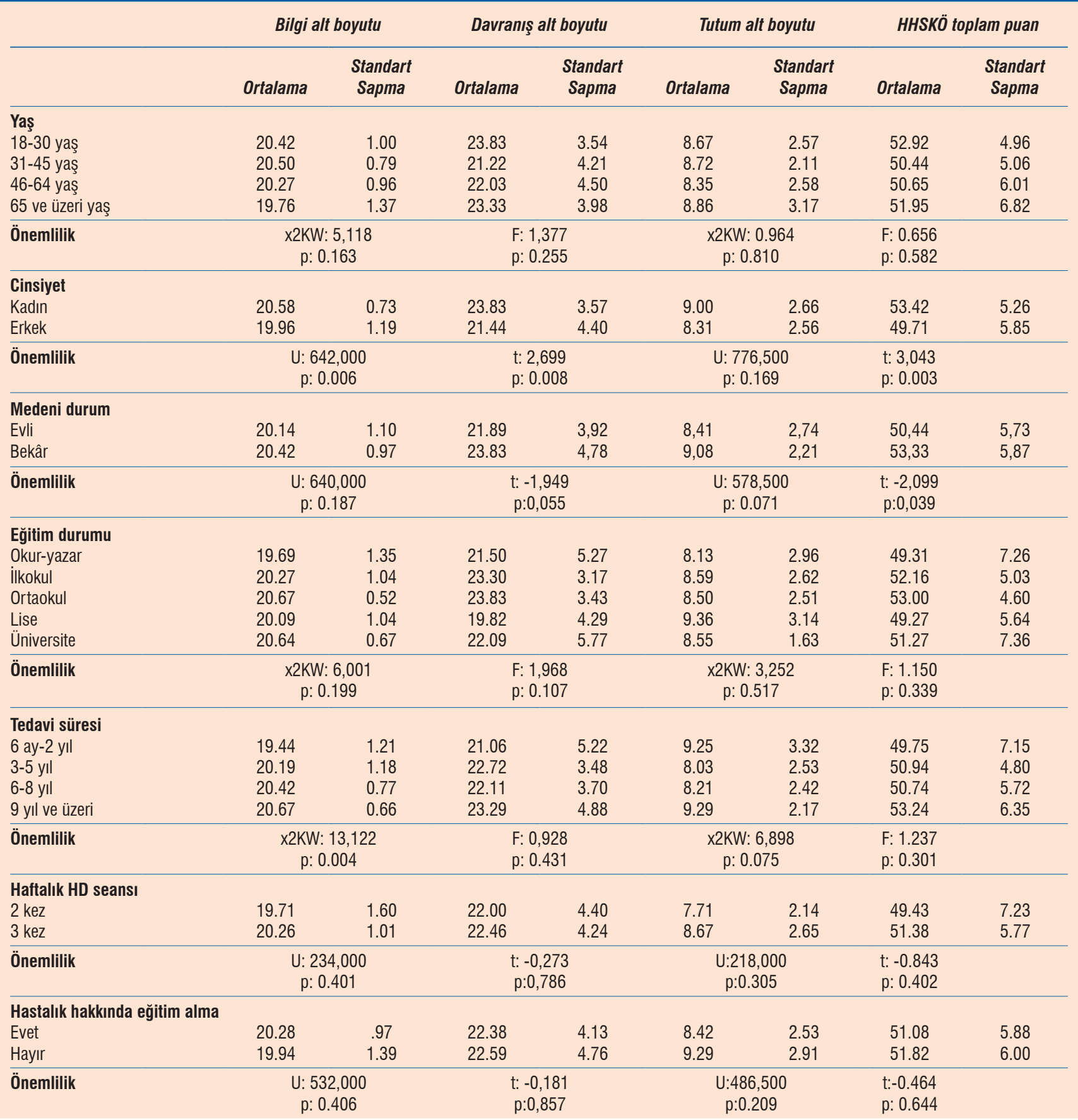

Hastaların medeni durumlarına göre HHSKÖ toplam puanları açısından aldıkları puanlar arasındaki fark istatistiksel olarak anlamlı iken ( $p<0.05)$, "Bilgi" alt boyutu, "davranış" alt boyutu ve "Tutum" alt boyutu açısından aldıkları puanlar arasındaki fark istatistiksel olarak anlamsız bulunmuştur ( $p>0.05$ ) (Tablo 5). Bekar olan hastaların "HHSKÖ toplam puanları" aritmetik ortalamasının evli olan hastalardan daha yüksek olduğu görülmüştür.
Hastaların eğitim durumlarına göre HHSKÖ "Bilgi" alt boyutu, "Davranış" alt boyutu, "Tutum" alt boyutu ve "HHSKÖ toplam puanları" açısından aldıkları puanlar arasındaki fark istatistiksel olarak anlamsız bulunmuştur ( $p>0.05$ ) (Tablo 5).

Hastaların HD tedavi süresine göre HHSKÖ "Bilgi" alt boyutu açısından aldıkları puanlar arasındaki fark istatistiksel olarak anlamlı iken $(p<0.05)$, “Davranış" alt boyutu, “Tutum” alt 
Tablo 6. Hastaların IDWG ve UF miktarı ile HHSKÖ puanları arasındaki ilişki

\begin{tabular}{|lccc|}
\hline & & IDWG & UF miktarı \\
\hline Bilgi alt boyutu & $r$ & -0.077 & -0.095 \\
Davranıs alt boyutu & $p$ & 0.476 & 0.380 \\
& $r$ & -0.201 & -0.258 \\
\hline Tutum alt boyutu & $p$ & 0.060 & 0.001 \\
& $r$ & -0.365 & -0.359 \\
\hline HHSKÖ toplam puan & $p$ & 0.000 & 0.001 \\
& $r$ & -0.299 & -0.363 \\
& $p$ & 0.005 & 0.001
\end{tabular}

boyutu ve "HHSKÖ toplam puanları" açısından aldıkları puanlar arasındaki fark anlamsız bulunmuştur $(p>0.05)$ (Tablo 5). Farkın hangi gruptan kaynaklandığını belirlemek için yapılan ileri analizde (Mann Whitney U) tedavi süresi 6 ay-2 yıl olan hastaların, tedavi süresi 3-5 yıl, 6-8 yıl ve 9 yıl ve üzeri olan hastalardan düşük olduğu saptanmıştır.

Hastaların haftalık HD seansına göre HHSKÖ "Bilgi" alt boyutu, "Davranış", "Tutum" alt boyutu ve "HHSKÖ toplam puanları" açısından aldıkları puanlar arasındaki fark istatistiksel olarak anlamsız bulunmuştur ( $p>0.05$ ) (Tablo 5).

Hastaların hastalık ve tedavi süreci hakkında eğitim alma durumlarına göre HHSKÖ "Bilgi" alt boyutu, "Davranış" alt boyutu, "Tutum" alt boyutu ve "HHSKÖ toplam puanları" açısından aldıkları puanlar arasındaki fark istatistiksel olarak anlamsız bulunmuştur ( $p>0.05$ ) (Tablo 5 ).

Hastaların bilgi alt boyut puanları ile IDWG ve UF miktarı arasında istatistiksel olarak anlamlı bir ilişki olmadığı bulunmuştur ( $p>0.05$ ). Hastaların davranış alt boyut puanı ile IDWG arasında istatistiksel olarak anlamlı bir ilişki yokken ( $p>0.05)$, UF miktarı ile negatif yönlü düşük düzeyli anlamlı ilişki bulunmuştur ( $p<0.05)$. Davranış puanı artarken, UF miktarı düşmektedir. Hastaların tutum alt boyut puanı ile IDWG ve UF miktarı arasında istatistiksel olarak negatif yönlü düşük düzeyli anlamlı bir ilişki bulunmuştur ( $p<0.05)$. Tutum alt boyut puanı artarken, IDWG ve UF miktarı düşmektedir. Hastaların HHSKÖ toplam puanı ile IDWG ve UF miktarı arasında istatistiksel olarak negatif yönlü düşük düzeyli anlamlı bir ilişki bulunmuştur ( $p<0.05)$. HHSKÖ toplam puanı artarken, IDWG ve UF miktarı düşmektedir (Tablo 6).

\section{Tartışma}

HD tedavisi alan bireylerin IWDG ve UF miktarı diğer araştırma sonuçları $(20,28,36,37)$ ile karşılaştırıldığında; örneklem grubumuzdaki bireylerin IWDG değeri ve UF miktarının diğer araştırmalardan yüksek olduğu belirlenmiştir. Bu sonuç hastaların sıvı alımı konusunda uyumlarının iyi olmadığını göstermektedir.

Sıvı fazlalığı, SDBY olan ve HD tedavisi alan bireylerin en önemli klinik sorunlarından biridir (38). Yapılan bu araştırmada, HD tedavisi alan bireylerin sIVı kısıtlamasına uyum düzeylerini değerlendirmek amacıyla HHSKÖ kullanılmıştır. HHSKÖ toplam puan ortalamasına göre bu araştırmadaki HD tedavisi alan bireylerin sIVı kısıtlamasına uyumları orta düzeyde bulunmuş olup, HHSKÖ alt boyut puan ortalamalarına göre; bu bireylerin sıvı kısıtlaması bilgi düzeylerinin yüksek olduğu, davranış boyutu açısından orta seviyede bir uyuma sahip oldukları ve tutum boyutunda ise uyum düzeylerinin düşük olduğu görülmüştür. Albayrak Coşar'ın (2012) yaptığı araştırmada; HHSKÖ toplam puan ortalamasına göre HD tedavisi alan bireylerin sıvı kısıtlamasına uyumları orta düzeyde bulunmuş olup, HHSKÖ alt boyut puan ortalamalarına göre; bu bireylerin sıvı kısıtlaması bilgi düzeylerinin yüksek olduğu, davranış boyutu açısından yüksek oranda bir uyuma sahip oldukları ve tutum boyutunda ise uyum düzeylerinin düşük olduğu görülmüştür (35). Balım ve Çınar Pakyüz'ün (2016) yaptığı araştırmada ise; HHSKÖ toplam puan ortalamasına göre HD tedavisi alan bireylerin sıvı kısıtlamasına uyum düzeyleri düşük bulunmuş olup, HHSKÖ alt boyut puan ortalamalarına göre; bu bireylerin sıvı kısıtlaması bilgi düzeylerinin düşük olduğu, davranış boyutu ve tutum boyutu açısından da orta seviyede bir uyuma sahip oldukları görülmüştür (36). Yaptığımız bu araştırmadaki HD tedavisi alan bireylerin sıvı kısıtlamasına uyum düzeyleri, Albayrak Coşar'ın (2012) yaptığı araştırmada bulunan HD tedavisi alan bireylerin sıvı kısıtlamasına uyum düzeylerinden düşük, Balım ve Çınar Pakyüz'ün (2016) yaptığı araştırmadaki HD tedavisi alan bireylerin sıvı kısıtlamasına uyum düzeylerinden yüksek bulunmuş olup, bu araştırmadaki HD tedavisi alan bireylerin SIVı kısıtlaması bilgi düzeyleri her iki araştırmadaki bireylerin sıvı kısıtlaması bilgi düzeylerinden yüksek, tutum düzeylerinden düşük bulunmuştur. Yapılan birçok araştırma sonucunda HD tedavisi alan bireylerin sıvı alımı konusunda uyumsuz oldukları görülmektedir $(4,20,30,37,38,39,40,41,42)$.

HD tedavisi alan bireylerin tanıtıcı ve hastalıkla ilişkili özelliklerine göre sıvı kontrol uyum düzeyleri incelendiğinde; cinsiyetin, medeni durumun ve tedavi süresinin sıvı kontrol uyum düzeyini etkilediği belirlenmiştir. Kadınların tutum alt boyutu hariç diğer alt boyut ve toplam sıvı kontrol uyum düzeylerinin erkeklerden daha yüksek olduğu bulunmuş olup, Kugler ve ark.'nın (2005), Iborra-Moltó ve ark.'nın (2012) yaptığı araştırmalarda 
benzer sonuç (43,44), Takaki ve Yano'nun (2006), Chilcot ve ark.'nın (2010) yapmış olduğu araştırmalarda da tam tersi sonuçlar elde edilmiştir $(30,45)$. Konuyla ilgili diğer araştırmalarda ise cinsiyetin sıvı kontrol uyumlarında farklılık oluşturmadığı tespit edilmiştir $(37,39,40,42)$. Balım ve Çınar Pakyüz'ün (2016) yaptığı araştırmada cinsiyete göre sıvı kontrol uyum düzeyleri arasında anlamlı bir fark saptanmazken, IDWG açısından kadınların daha uyumlu olduğu görülmüştür (36). Molaison ve Yadrick'in (2003) ve Cristóvão'nun (2015) yaptığı çalışmaların sonucu da IDWG açısından kadınların daha uyumlu olduğunu göstermektedir $(22,26)$. Kadınların sıvı kontrolüne ilişkin uyum düzeylerinin daha yüksek olması, bizim hasta grubumuzdaki kadınların evde daha fazla zaman geçiriyor olmaları ve bu doğrultuda kendi tedavi süreçlerine ayırdıkları zamanın fazla olması ve aynı zamanda yemek yapan kişi olarak diyete uygun besin hazırlama işlemini gerçekleştiriyor olmaları ile ilişkilendirilebilir.

Medeni duruma göre sıvı kontrol uyumlarının değerlendirilmesinde; bekar olan hastaların toplam sıvı kontrol uyum düzeylerinin evlilerden daha yüksek olduğu bulunmuştur. Konuyla ilgili araştırmalarda farklı sonuçlar elde edilmiştir. Ahrari ve ark.'nın (2014), Korkmaz'ın (2016) ve Erdem'in (2012) yapmış olduğu araştırmalarda evli hastaların sıvı kontrol uyum düzeylerinin daha yüksek olduğu tespit edilirken (20,40,42), Efe ve Kocagöz'ün (2015), Balım ve Çınar Pakyüz'ün (2016) yapmış olduğu araştırmalar sonucunda ise medeni durumun sIvı kontrol uyumunda önemli belirleyici olmadığı belirlenmiştir $(36,39)$. Bekarların sıvı kontrolüne ilişkin uyum düzeylerinin daha yüksek olması, bizim hasta grubumuzdaki bekarların aile sorumluluğu gibi önemli sorumluluklarının olmaması, daha genç olmaları nedeniyle hayata daha sıkı bağlanmaları ve geleceğe dair ümitlerinin fazla olması ile ilişkilendirilebilir.

HD tedavi süresine göre sıvı kontrol uyumlarının değerlendirilmesi sonucunda; HD tedavi süresi 6 ay-2 yıl olan hastaların diğer gruplara göre sıvı kontrolüne ilişkin bilgi düzeylerinin daha düşük olduğu bulunmuştur. HD tedavi süresi arttıkça, hastaların sıvı kontrol uyumu bilgi düzeyleri de artmaktadır. Bu araştırma sonucuna benzer şekilde HD tedavi süresinin artması ile sIVı kontrol uyumunun arttığını gösteren araştırmalar mevcut iken $(26,41)$, tam tersi sonucun elde edildiği araştırmalar da mevcuttur $(30,43)$.
HD tedavi süresi arttıkça sağlık personeli ile geçirilen zaman da artmaktadır. Dolayısıyla hastalar bu süreçte hastalık ve semptomların kontrolüne yönelik daha fazla bilgi edinmektedir. Ayrıca bu süreçte yaşayarak öğrenmenin etkisi olduğu düşünülmektedir.

HD tedavisi alan bireylerin IDWG ile sıvı kontrol uyumları arasındaki ilişki incelendiğinde; bireylerin IDWG'leri ile tutum alt boyut ve toplam sıvı kontrol uyum düzeyleri arasında negatif yönlü düşük düzeyli anlamlı bir ilişki bulunmuştur. Hastaların sıvı kontrolü uyumunda tutum ve toplam puanları arttıkça IDWG'nin azaldığı tespit edilmiştir. Kugler ve ark.'nın (2005), Efe ve Kocagöz'ün (2015), Ahrari ve ark.'nın (2014) yapmış olduğu araştırmalarda da benzer sonuç elde edilmiştir $(20,39,44)$. Günalay ve ark.'nın (2017) yaptığı araştırma sonucunda ise IDWG ile sıvı kontrol uyum düzeyi arasında anlamlı bir ilişki saptanmamıştır (37). IDWG sıvı kontrol uyumunu değerlendirmede dikkate alınan önemli parametrelerden biri olup, sıvı kontrol uyumuna ilişkin iyileşmenin görüldüğü bireylerde IDWG'de düşüş beklenir.

Hastaların UF miktarı ile sıvı kontrol uyumları arasındaki ilişki incelendiğinde; HD tedavisi alan bireylerin UF miktarı ile davranış alt boyut, tutum alt boyut ve toplam sıvı kontrol uyum düzeyleri arasında negatif yönlü düşük düzeyli anlamlı bir ilişki bulunmuş olup, hastaların sıvı kontrol uyumunda davranış ve toplam puanları arttıkça UF miktarının azaldığı belirlenmiştir. UF miktarı IDWG ile yakından ilişkili olup, sıvı kontrol uyumunun artması ile UF'nin azalması beklenen bir sonuçtur.

\section{Sonuç}

HD tedavisi alan bireylerin sıvı kısıtlamasına yeterince uyum geliştiremedikleri, kadınlar ve bekarların uyum düzeylerinin daha iyi olduğu, tedavi süresi uzun olan bireylerin sıvı kısıtlaması bilgi düzeylerinin daha yüksek olduğu ve sıvı kısıtlamasına uyumun artması ile IWDG ve UF miktarlarının azaldığı sonuçları elde edilmiştir. Sıvı kısıtlamasına uyumun arttırılması ile mortalite ve mobidite oranları azaltılabilecektir. Bu doğrultuda; her hastaya özel uyumu arttırmaya yönelik bilgi, tutum ve davranış boyutunda değişiklik oluşturabilecek ve sıvı kontrolüne ilişkin farkındalık düzeyini arttıracak eğitim ve uygulamalara ihtiyaç vardır. 


\section{Kaynaklar}

1. Yağcı N, Ağırcan D. Son Dönem Böbrek Yetersizliğinin Mobilite ve Denge Üzerine Etkisinin İncelenmesi: Kontrollü Bir Çalışma. Türk Nefroloji Diyaliz ve Transplantasyon Dergisi 2012;21:262-66.

2. Süleymanlar G, Ateş K, Seyahi N. Türkiye'de Nefroloji, Diyaliz ve Transplantasyon. Ankara: Türk Nefroloji Derneği 2015:1-3.

3. Sungur G, Tekinsoy B, Ceyhan Ö, Taşçı S, Şahin S, Göriş S. Hemodiyaliz Hastalarının Evde Bakım Gereksinimleri. Nefroloji Hemşireliği Dergisi 2009;6:17-21.

4. Denhaerynck K, Manhaeve D, Dobbels F, Garzoni D, Nolte C, De Geest S. Prevalence and Consequences of Nonadherence to Hemodialysis Regimens. Am J Crit Care 2007;16:222-35.

5. Karadakovan A, Eti Aslan F. Dahili ve Cerrahi Hastalıklarda Bakım. Adana: Nobel Kitabevi, 2011:937-41.

6. Durna Z. İç Hastalıkları Hemşireliği. İstanbul: Akademi Basın ve Yayıncılık, 2013:468-81.

7. Koç Z, Sağlam Z. Hemodiyaliz Hastalarının Yalnızlık Düzeylerinin Belirlenmesi. Nefroloji Heşireliği Dergisi 2009;6:29-36.

8. Öztürk B, Akın S, Durna Z, Özdilli K. Hemodiyaliz Tedavisini Sürdüren Hastalarda Fonksiyonel Performans Durumu, Yaşam Kalitesi ve Fistül Bakımı lle İlişkili Bilgi Düzeyinin Değerlendirilmesi. Nefroloji Hemşireliği Dergisi 2013;1:24-38.

9. Ovayolu N, Ovayolu Ö. Hemodiyaliz Yeterliliğinin Yaşam Kalitesine Etkisi. Nefroloji Hemşireliği Dergisi 2013;1:39-52.

10. Yılmaz Karabulutlu E, Okanlı A. Hemodiyaliz Hastalarında Hastalık Algısının Değerlendirilmesi. Anadolu Hemşirelik ve Sağlık Bilimleri Dergisi 2011;14:25-30.

11. Khalil AA, Frazier SK, Lennie TA, Sawaya BP. Depressive Symptoms and Dietary Adherence in Patients With End-Stage Renal Disease. J Ren Care 2011;37:30-9. [CrossRef]

12. Afrasiabifar A, Karimi Z, Hassani P. Roy's Adaptation Model-Based Patient Education For Promoting The Adaptation of Hemodialysis Patients. Iran Red Crescent Med J 2013;15:566-72. [CrossRef]

13. Kral Ü, Yurtsever S. Kuzey Kıbrıs Türk Cumhuriyetinde Yaşayan Hemodiyaliz Hastalarının Yaşam Kalitesi. Nefroloji Hemşireliği Dergisi 2013;1:61-76.

14. Başarır S, Çınar Pakyüz S. Hemodiyaliz Hastalarının Sağlıklı Yaşam Biçimi Davranışlarının Değerlendirilmesi. Nefroloji Heşireliği Dergisi 2015;1:19-31.

15. Turgut Kurt $\mathrm{Y}$, Erdem E, Kaya C, Karataş A, Arık N. Hemodiyaliz Hastalarına Verilen Eğitimin Kan Basıncı ve Kilo Alımına Etkisi. Türk Nefroloji Diyaliz ve Transplantasyon Dergisi 2012;21:39-44.

16. Kara B. Hemodiyaliz Hastalarında Tedaviye Uyum: Çok Yönlü Bir Yaklaşım. Gülhane Tıp Dergisi 2007;49:132-36.

17. Alkatheri AM, Alyousif SM, Alshabanah N, Albekairy AM, Alharbi S, Alhejaili FF, Alsayyari AA, Qandil AM. Medication Adherence Among Adult Patients on Hemodialysis. Saudi J Kidney Dis Transpl 2014;25:762-8.

18. Saran R, Bragg-Gresham JL, Rayner HC, Goodkin DA, Keen ML, Van Dijk PC, et al. Nonadherence in Hemodialysis: Associations With Mortality, Hospitalization and Practice Patterns in The DOPPS. Kidney Int 2003;64:254-62. [CrossRef]

19. Howren MB, Kellerman QD, Hillis SL, Cvengros J, Lawton W, Christensen AJ. Effect of A Behavioral Self-Regulation Intervention on Patient Adherence to Fluid-Intake Restrictions in Hemodialysis: A Randomized Controlled Trial. Ann Behav Med 2016;50:167-76. [CrossRef]

20. Ahrari S, Moshki M, Bahrami M. The Relationship Between Social Support and Adherence of Dietary and Fluids Restrictions Among Hemodialysis Patients in Iran. J Caring Sci 2014;3:11-9. [CrossRef]

21. Winters AM, Lindberg M, Sol BGM. Validation of A Dutch SelfEfficacy Scale For Adherence to Fluid Allowance Among Patients on Haemodialysis. J Ren Care 2013;39:31-8. [CrossRef]
22. Cristóvão AFAJ. Fluid and Dietary Restriction's Efficacy on chronic Kidney Disease Patients in Hemodialysis. Rev Bras Enferm 2015;68:842-50.

23. Lindberg M, Wikstrfm B, Lindberg P. Fluid Intake Appraisal Inventory: Development and psychometric Evaluation of A Situation-Specific Measure For Haemodialysis Patients' Self-Efficacy to Low Fluid Intake. J Psychosom Res 2007;63:167-73. [CrossRef]

24. Welch JL, Thomas-Hawkins C. Psycho-educational Strategies to Promote Fluid Adherence in Adult Hemodialysis Patients: A Review of Intervention Studies. Int J Nurs Stud 2005;42:597-608. [CrossRef]

25. Fernandes MI, Mendeiros AB, Macedo BM, Vitorino AB, Lopes MV, Lira AL. Prevalence of Nursing Diagnosis of Fluid Volume Excess in Patients Undergoing Hemodialysis. Rev Esc Enferm USP 2014;48:446-53.

26. Molaison EF, Yadrick MK. Stages of Change and Fluid Intake in Dialysis Patients. Patient Educ Couns 2003;49:5-12.

27. lacono SA. Medication Side Effects: Barriers to The Management of Fluid Intake. Dialysis \& Transplantation 2008;37:196-201.

28. Wizemann V, Wapel P, Chamney P, Zaluska W, Moissl U, Rode C, et al. The Mortality Risk of Overhydration in Hemodialysis Patients. Nephrol Dial Transplant 2009;24:1574-9. [CrossRef]

29. Stegmayr BG, Brannstrom M, Bucht S, Dimeny E, Ekspong A, Granroth $B$, et al. Minimized Weight Gain Between Hemodialysis Contributes to A Reduced Risk of Death. Int J Artif Organs 2006;29:675-80.

30. Chilcot J, Wellsted D, Farrington K. Illness Representations Are Associated With fluid Nonadherence Among Hemodialysis Patients. J Psychosom Res 2010;68:203-12. [CrossRef]

31. Sarkar SR, Kotanko P, Levin NW. Interdialytic weight gain: implications in hemodialysis patients. Semin Dial 2006:429-33. [CrossRef]

32. Raimann J, Liu L, Ulloa D, Kotanko P, Levin NW. Consequences of Overhydration and The Need For Dry Weight Assessment. in Hemodialysis-From Basic Research to Clinical Trials. Ronco C and Cruz DN Eds. Contrib Nephrol 2008;161:99-107. [CrossRef]

33. Lindley E. Aspinall L, Gardiner C, Garthwaite E. Management of Fluid Status in Haemodialysis Patients: The Roles of Technology and Dietary Advice. in Technical Problems in Patients on Hemodialysis. Penido MG Eds. InTech. 2011;185-99. [CrossRef]

34. Kara B. Diyaliz Diyet ve Sıvı Kısıtlamasına Uyumsuzluk Ölçeğin'in Geçerlik ve Güvenirlik Çalışması. Atatürk Üniversitesi Hemşirelik Yüksekokulu Dergisi 2009;12:20-7.

35. Albayrak Coşar A. Ölçek Geliştirme Çalışması: Hemodiyaliz Hastalarında Sıvı Kontrolü. İstanbul: Marmara Üniversitesi; 2012.

36. Balım S, Çınar Pakyüz S. Hemodiyaliz hastalarının Sıvı Kontrolüne Uyumlarının Değerlendirilmesi. Nefroloji Hemşireliği Dergisi 2016;1:34-42.

37. Günalay S, Taşkıran E, Mergen H. Hemodiyaliz hastalarında Diyet ve Sıvı Kısıtlamasına Uyumsuzluğunun Değerlendirilmesi. FNG \& Bilim Tıp Dergisi 2017;3:9-14. [CrossRef]

38. Lindberg M. Excessive Fluid Overload among Haemodialysis Patients: Prevalence, Individual Characteristics and Self-regulation of Fluid Intake. Acta Universitatis Upsaliensis; 2010.

39. Efe D, Kocaöz S. Adherence to Diet and Fluid Restriction of Individuals on Hemodialysis Treatment and Affecting Factors in Turkey. Japan Journal of Nursing Science 2015;12:113-23. [CrossRef]

40. Korkmaz Y. Hemodiyaliz Hastalarının Tedavi ve Sıvı Kısıtlamasına Uyum, Uyumsuzluk ve Öz Etkililik Durumunun İncelenmesi. Ankara Başkent Üniversitesi 2016.

41. Yokoyama Y, Suzukamo Y, Hotta O, Yamazaki S, Kawaguchi $T$, Hasegawa $T$, et al. Dialysis staff encouragement and fluid control adherence in patients on hemodialysis. Nephrol Nurs J 2009:36:289-98 
42. Erdem E. Hemodiyaliz Hastalarında Sıvı Kısıtlamasına Uyum, Tuz Bilgisi ve Yiyecek Tüketim Alışkanlıkları. Samsun: Onokuz Mayıs Üniversitesi; 2012.

43. Iborra-Moltó C1, López-Roig S, Pastor-Mira Mde L. Prevalence of adherence to fluid restriction in kidney patients in haemodialysis: objective indicator and perceived compliance. Nefrologia 2012;32:477-85. [CrossRef]
44. Kugler C, Vlaminck H, Haverich A, Maes B. Nonadherence With Diet and Fluid Restrictions Among Adults Having Hemodialysis. J Nurs Scholarsh 2005;37:25-9.

45. Takaki J, Yano E. Possible gender Differences in The Relationships of Self-Efficacy and The Internal Locus of Control with Compliance in Hemodialysis Patients. Behav Med 2006;32:5-11. [CrossRef] 